\title{
Gözlü ve Altınova Tarım İşletmelerinde Islah Edilen Korunga Çeşitlerinin Verim ve Bazı Tarımsal Özellikleri Üzerine Ön Araştırmalar
}

\author{
Ali KOÇ ${ }^{1} \quad$ Hakkı AKDENIZ ${ }^{2}$ \\ ${ }^{1}$ Tarım İşletmeleri Genel Müdürlüğü, AR-GE Şube Müdürlüğü, Ankara \\ ${ }^{2}$ Iğdır Üniversitesi, Ziraat Fakültesi, Tarla Bitkileri Bölümü, Iğdır \\ $\triangle$ : alikoc6164@hotmail.com
}

\begin{abstract}
ÖZET: Bu çalışma, TİGEM İşletmesine ait Altınova ve Gözlü tarım işletmelerinde sslah edilen korunga çeşitlerinin Koç 1461, Emre, Yunus, Fatih, Mehmetalibey ve Hilal çeşitleri İle standart çeşit olarak kullanılan Özerbey ve Lütfübey çeşitlerinin verim ve bazı tarımsal özelliklerini incelemek amacıyla 2014 ve 2015 yılarında yapılmıştır. Deneme iki ayrı yerde, tesadüf blokları deneme desenine göre 4 tekrarlamalı olarak yürütülmüştür. Çeşitlerin verim ve bazı tarımsal özellikleri yıllara ve lokasyonlara bağlı olarak değişim göstermiştir.

Yıllar ve lokasyonların ortalaması olarak yaş ot verimleri $(2077.3-2674.9 \mathrm{~kg} / \mathrm{da})$, kuru ot verimleri $(456.9-575.1$ $\mathrm{kg} / \mathrm{da}$ ), çiçeklenme gün sayısı (135.0-140.8 gün), ana sap uzunluğu (90.5-100.8 cm), ana sap kalınlığ 5.7-6.7 mm), ana sap sayısı (15.0-18.0 adet), yatma durumu (1-3), 1-5 skalasına göre), seyrekleşme oranı (\% 18.9-20.7), kışa dayanıklılık (\%92.5-95.3) olarak bulunmuştur. Yıllar ve lokasyonların ortalaması olarak en yüksek kuru ot verimi 575.1 ile $564.1 \mathrm{~kg} / \mathrm{da}$ verim Emre ve Koç 1461 çeşidinden, en düşük verim ise $534.5 \mathrm{~kg} / \mathrm{da}$ ile Özerbey çeşidinden elde edilmiştir.

Denemesin sonuçlarına göre, ana sap uzunluğu üzerinde lokasyon, yıl x çeşit interaksiyonu önemsiz, yaş ve kuru ot verimler dahil diğer bütün tarımsal karakterler üzerinde yıl, yıl x lokasyon, lokasyon x çeşit, yıl x çeşit, yıl x lokasyon x çeşit interaksiyonları çok önemli bulunmuştur.

Anahtar Kelimeler: Korunga, Onobrychis sativa L., çeşit, verim ve tarımsal özellikler

\section{Preliminary Investigations on the Yield and Some Agricultural Properties of Sainfoin (Onobrychis sativa L.) Species of Breed in Gözlü and Altmova Agricultural Establishments}

ABSTRACT: The objective of this experiment was to investigate the yields and some agricultural characteristics of the varieties of Özerbey and Lutfübey which are used as standard varieties with Koç 1461, Emre, Yunus, Fatih, Mehmetalibey and Hilal varieties of sainfoin grown in Altınova and Gözlü agriculture enterprises belonging to TIGEM in 2014 and 2015. The experiment was carried out completely randomized blocks design with 4 replicates. The yield and some agricultural characteristics of the varieties varied depending on years and locations. As averages of years and locations, green herbage yield (2077.3-2674.9 kg / da), hay yield (456.9-575.1 kg/da), number of flowering days (135.0-140.8 days), main stem length $(90.5-100.8 \mathrm{~cm})$, plant density ratio $(18.9-20.7 \%)$, winter resistance (92.595.3\%), the number of main stems (15.0-18.0), lodging ratio (1-3). The highest hay yields (575.1 and $564.1 \mathrm{~kg} / \mathrm{da}$ ) were obtained as the average of years and locations. Emre and Koç 1461 variety had the highest yield and the lowest yield was obtained from the Özerbey variety with $534.5 \mathrm{~kg} / \mathrm{da}$. According to the results of the experiment, year and the interactions of year $\mathrm{x}$ location, location $\mathrm{x}$ variety, year $\mathrm{x}$ variety, year $\mathrm{x}$ location $\mathrm{x}$ variety were found to be very important depending on all other agricultural characters including.

Keywords: Sainfoin, Onobrychis sativa L., variety, yield, agricultural traits

\section{GíRiş}

Korunga bitkisi (Onobrychis sativa Lam.), kurak şartlara uyum sağlamasının yanında, hayvan beslenmesindeki önemi, toprağa azot fikse etmesi su kapasitesinin artırması suni mera tesisinde ve doğal meralarda yer alması, eğimli sahalarda toprak kaybını önlemesi ve iyi bir balözü bitkisi olması sebebiyle oldukça önemli bir kültür bitkisidir (Manga ve ark., 1995; Lu ve ark. 2000; Elçi, 2005; Serin ve Tan, 2008; Delgado ve ark., 2008; Özbek 2011). Korunga konsantre tane içeriklerinden dolayı geviş getiren hayvanların sindirim organlarında metan ve amonyak gazını azaltıp hayvanların sağlığı ve verimi üzerine çok önemli bir katkısı bulunmaktadır (Rumball and Claydon 2005; Häring ve ark. (2007b). Ülkemizde en fazla yetiştirilen yem bitkileri arasında yonca, silajlık misır, fiğ ve korunga yer almaktadır (Anonim, 2015). Dilera ve ark.
(2016), 378 sığır üreticisi ile yapmış olduğu bir anket çalışması sonucuna göre hayvan besleme alışkanlıklarında bazı yanlışlıklar olmakla birlikte işletme sahiplerinin \% 16'sının yem bitkisi yetiştiriciliği yaptığ 1 ve bunların \% 80'inde korunga tarımı yapıldığ bildirilmektedir. Türkiye İstatistik Kurumu verilerine göre, mevcut tarım arazisi miktarı 239.430.534.60 dekardır (Anonim, 2015). Ülkemizde korunga 2014 yılı 1.949.088 dekar ekim alanı 3 yılda bir yenileme süresine göre yılda 5.197 ton tohuma ihtiyaç duyulmaktadır. Bu miktarın 46 tonu karşılanmakta bu değer \% 0.9 'a tekabül etmektedir (Anonim, 2014). Bunun nedeni çeşit azlığı ve yeteri kadar elit üretimin gerçekleşmemesinden kaynaklanmaktadır.

$\mathrm{Bu}$ amaçla TİGEM bu sorunu çözmek için korunga ıslahına başlamış ve popülasyondan elde edilen bitkilerle sentetik varyete 1slahı ile Koç1461, Emre, 
Yunus, Fatih, Mehmetalibey ve Hilal olmak üzere toplam 6 çeşit adayı elde edilmiştir. Türkiye'de önemli ölçüde düşüş gösteren sertifikalı korunga tohum üretimini, kısa sürede \%50 seviyelere çıkararak Türk çiftçisinin hizmetine sunmaktadır.

$\mathrm{Bu}$ araştırma, Altınova ve Gözlü Tarım İşletmesinde, sentetik varyete yöntemiyle sslah edilmiş olan 6 çeşit korunga adayının ot ve bazı tarımsal özelliklerinin ortaya koymak amacıyla yapılmıştır.

\section{MATERYAL ve METOT}

Çizelge 1. Korunga çeşit denemesinin yürütüldüğü lokasyonların bazı toprak analiz sonuçları

\begin{tabular}{|l|l|l|l|l|l|l|l|l|l|l|}
\hline Lokasyonlar & $\begin{array}{c}\text { Derinlik } \\
(\mathrm{cm})\end{array}$ & $\begin{array}{c}\text { Su ile } \\
\text { doygunluk }\end{array}$ & Bünye & $\begin{array}{c}\text { EC }(\mathrm{dS} .18 . \mathrm{dS} \\
\mathrm{m})\end{array}$ & $\begin{array}{c}\text { Toplam } \\
\text { Tuz }(\%)\end{array}$ & $\mathrm{pH}$ & $\begin{array}{c}\text { Kireç } \\
(\%)\end{array}$ & $\begin{array}{c}\text { P2O5 } \\
(\mathrm{kg})\end{array}$ & $\begin{array}{c}\text { K2O5 } \\
(\mathrm{kg})\end{array}$ & $\begin{array}{c}\text { Organik } \\
\text { madde }(\%)\end{array}$ \\
\hline Altınova & $0-30$ & 48 & $\mathrm{~L}$ & 1.428 & 0.044 & 7.67 & 12.89 & 13.79 & 153.87 & 2.01 \\
\hline Gözlü & $0-30$ & 72 & $\mathrm{C}$ & 0.861 & 0.040 & 7.44 & 25.53 & 8.48 & 141.99 & 1.93 \\
\hline
\end{tabular}

Çizelge 2. Korunga çeşit denemesinin yürütüldüğü lokasyonların bazı iklim verileri ve uzun yıllar ortalaması (UY)

\begin{tabular}{|c|c|c|c|c|c|c|c|c|c|c|c|c|c|c|c|c|c|c|}
\hline \multirow[t]{3}{*}{ Aylar } & \multicolumn{6}{|c|}{$\begin{array}{l}\text { Ortalama Aylık Sicaklık } \\
(\mathrm{oC})\end{array}$} & \multicolumn{6}{|c|}{ Ortalama Aylık Yağış (mm) } & \multicolumn{6}{|c|}{$\begin{array}{l}\text { Ortalama Aylık Nispi nem } \\
(\%)\end{array}$} \\
\hline & \multicolumn{3}{|c|}{ Altınova } & \multicolumn{3}{|c|}{ Gözlü } & \multicolumn{3}{|c|}{ Altınova } & \multicolumn{3}{|c|}{ Gözlü } & \multicolumn{3}{|c|}{ Altınova } & \multicolumn{3}{|c|}{ Gözlü } \\
\hline & $\begin{array}{l}201 \\
4\end{array}$ & $\begin{array}{l}201 \\
5\end{array}$ & $\mathrm{UY}$ & $\begin{array}{l}201 \\
4\end{array}$ & $\begin{array}{l}201 \\
5\end{array}$ & $\mathrm{UY}$ & $\begin{array}{l}201 \\
4\end{array}$ & $\begin{array}{l}201 \\
5\end{array}$ & $\mathrm{UY}$ & $\begin{array}{l}201 \\
4\end{array}$ & $\begin{array}{l}201 \\
5\end{array}$ & UY & \begin{tabular}{|l|}
201 \\
4
\end{tabular} & $\begin{array}{l}201 \\
5\end{array}$ & UY & $\begin{array}{l}201 \\
4\end{array}$ & $\begin{array}{l}201 \\
5\end{array}$ & UY \\
\hline Ocak & -1.4 & -1.4 & -3.22 & 0.6 & -3 & -3.22 & 33 & 35 & 27.9 & 40 & 18.6 & 29.1 & 72.5 & 92.9 & 86.54 & 86.6 & 86 & 81.4 \\
\hline Şubat & 5.8 & 5.8 & -2.3 & 2.2 & 1.6 & -2.3 & 10 & 58 & 25 & 4 & 18.9 & 24.7 & 60.7 & 96.8 & 79.58 & 65.1 & 78.9 & 62.08 \\
\hline Mart & 7.4 & 7.4 & 2.52 & 6.3 & 2.5 & 2.52 & 64 & 61 & 36.8 & 41.4 & 41.7 & 35.5 & 65.4 & 71.1 & 69.08 & 65.2 & 84.5 & 72.36 \\
\hline Nisan & 12.7 & 12.7 & 8.02 & 7.9 & 8.6 & 8.02 & 10.5 & 39 & 42.5 & 12.7 & 14.1 & 41.4 & 55.8 & 66.7 & 62.02 & 55.7 & 66.2 & 62.82 \\
\hline Mayıs & 15.4 & 15.4 & 15.38 & 15.6 & 13.3 & 15.38 & 49 & 79 & 34.9 & 30 & 53 & 34.5 & 63 & 54.1 & 61.12 & 60.4 & 40 & 58.58 \\
\hline Haziran & 17.7 & 17.7 & 19.38 & 16.6 & 16.2 & 19.38 & 47 & 88 & 28.1 & 42 & 84 & 27.3 & 64.6 & 75.8 & \begin{tabular}{|l|l|}
58.1 \\
\end{tabular} & 56 & 40.1 & 42.26 \\
\hline Temmuz & 23.8 & 23.8 & 22.96 & 22.7 & 20.9 & 22.96 & 3 & 0 & 9.5 & 2.5 & 0 & 7.2 & 42.5 & 44.6 & 42.1 & 42.5 & 35 & 40.26 \\
\hline A ğustos & 24.5 & 24.5 & 20.84 & 15 & 19 & 20.84 & 0 & 31 & 10.8 & 0 & 16.7 & 6 & 43.1 & 60 & 44.2 & 40.9 & 47.8 & 43.08 \\
\hline Eylül & 17.7 & 17.7 & 17.58 & 21.6 & 16.8 & 17.58 & 91 & 0 & 17.6 & 86 & 18 & 20.3 & 66.8 & 66.8 & 44.2 & 61 & 65.2 & 39.5 \\
\hline Ekim & 12.4 & 12.4 & 12.2 & 14.2 & 8.6 & 12.2 & 47 & 34 & 28.6 & 62 & 37 & 34.9 & 78.5 & 78.5 & 62.3 & 89.5 & 58.5 & 68.43 \\
\hline Kasım & 6.4 & 6.4 & 39.9 & 7.6 & 3.5 & 39.9 & 29.5 & 3.5 & 28 & 33 & 3 & 31.6 & 80 & 80 & 73.8 & 70.6 & 47.1 & 56.08 \\
\hline Aralık & 6.2 & 6.2 & 2.13 & & 1 & 2.13 & 32.5 & & 36 & 34.5 & & 42.9 & 90.6 & & 79.1 & 81.7 & & 78.35 \\
\hline Top./Ort & 12.4 & 11.9 & & 12.7 & 13.0 & & & & & & & & & & & & & \\
\hline
\end{tabular}

UY: Uzun yıllar yağış için 20 yıl, sıcaklık ve nispi nem için 5 yıllıktır.

Materyal: Denemede tescile aday 6 korunga (Koç1461, Emre, Yunus, Fatih, Mehmetalibey ve Hilal)

ile bu çeşitlerin karşılaştırılabileceği, önceki yıllarda tescil edilmiş 2 standart çeşit olan Lütfibey ve Özerbey çeşitleri kontrol olarak kullanılmıştır. Koç146, Emre, Yunus , Fatih , Mahmetalibey ve Hilal çeşit adaylarıdır.

Metot: Denemeler tesadüf blokları deneme desenine göre 4 tekrarlamalı olarak 2013 yılında kurulmuş ancak 2014 ve 2015 yllinda elde edilen veriler değerlendirmeye tabi tutulmuştur. Denemelerde dekara $10 \mathrm{~kg}$ tohum kullanılmıştır. Her parselde 8 sıra ve 50 $\mathrm{cm}$ sıra arası olacak şekilde, parsel uzunluğu $5 \mathrm{~m}$ üzerinden (Parsel alanı: $0.50 \mathrm{~cm}$ x 8 sira $\times 5$ parsel uzunluğu $=20 \mathrm{~m}^{2}$, hasat alanı ise $\left(0.5 \times 6 \times 4=12 \mathrm{~m}^{2}\right)$ üzerinden hasat yapılmıştır. Her iki yerde ekim 03.04.2013 tarihinde, tohum yatağı yabancı otlardan arındırıldıktan ve toprak iyice ufalandıktan sonra, $3 \mathrm{~cm}$ derinliğe elle yapılmış ve merdane ile bastırılmıştır. Ekimde $3 \mathrm{~kg} / \mathrm{da} \mathrm{N}$ (Amonyum Sülfat ve $6 \mathrm{~kg} / \mathrm{da} \mathrm{P}_{2} \mathrm{O}_{5}$ (Triple Süper Fosfat) verildi. Deneme boyunca hastalık ve zararlı görülmemiş ve yabancı ot mücadelesi çapa ile yapılmıștır. Her iki denemede çıkıșı kolaylaştırmak için bir kez sulama yapılmıştır.

\section{Yapılan Gözlemler}

Bütün gözlemler korunga biçilmeden önce her parselden rast gele seçilen 10 bitki üzerinde yapılmıştır.

1. Çiçeklenme gün sayısı (gün): Ekim tarihi ile parseldeki bitkilerin \% 10 çiçeklenmeye başladığ zamana kadar geçen süre gün olarak alınmıştır.

2. Ana Sap Uzunluğu (cm): Bitkinin toprak yüzeyi ile en tepe noktası arasında kalan mesafe $\mathrm{cm}$ olarak ölçülmüştür.

3. Ana Sap Kalınlı̆̆ (mm): Her parselden ana sapın 2. ve 3. boğum arasının kalınlığ $0.1 \mathrm{~mm}$ bölmeli kumpasla ölçülmüştür.

4. Ana Sap Sayısı (adet): Her parselden ana sapta bulunan dallar sayılmıştır.

5. Çiçek Rengi: Çiçek rengi gözle belirlenmiştir.

6. Yatma Durumu (1-5): Her parselde incelen bitkiler (1-5) 1skalasına göre; $1=$ dik, 2 = yarı dik,

$3=$ orta, 4= yarı yatık, 5= yatık şeklinde belirlenmiştir.

7. Seyrekleșme Oranı (\%): Biçimden sonra parseldeki bitkilerin seyrelme durumu gözle tahmin edilerek kayıt 
edilmiştir.

8. Kışa Dayanıklılık (\%): Korunga çeşitlerine ait parsellerde kış zararı gören bitkilerin oranı gözle tahmin edilerek belirlenmiştir.

9. Yeşil Ot Verimi ( $\mathrm{kg} / \mathrm{da})$ : Her parselin kenarlarından birer sıra, alt ve üst kısımlarından $0.5 \mathrm{~m}$ kısım biçilerek kenar tesiri olarak parselden uzaklaştırıldı. Geriye kalan alan biçilerek hasat edildi. Her parselden elde edilen yeşil ot hemen tartılarak dekara çevrildi.

10. Kuru Ot Verimi (kg/da): Her parselden elde edilen yeşil ot içerisinden rast gele $500 \mathrm{~g}$ örnek alınarak kurutma dolabında 48 saat $70{ }^{\circ} \mathrm{C}$ 'de kurutularak, kuru ot oranı bulunmuş ve yaş ot verimi ile çarpılarak dekara kuru ot verimi hesap edilmiştir.

Hasat: Hasat işlemi her lokasyona ait bitkiler $5 \mathrm{~cm}$ toprak seviyesinden bitkilerin $\% \quad 10$ çiçeklendiği dönemde yapılmıştır.

Verilerin Değerlendirilmesi: Her y1l elde edilen verimler ve diğer özellikler SAS paket programından yararlanılarak analiz edilmiş ve ortalamalar Duncan çoklu karşılaştırma testi ile mukayese edilmiştir.

\section{SONUÇLAR ve TARTIŞMA}

Yeni tescil edilmiş ve TÍGEM bağlı Altınova ve Gözlü Tarım İşletmesi arazilerinde 2 lokasyonlarında yürütülen korunga denemesinin yürütüldüğü alanlardan alınan toprak örneklerinin bazı değerleri Çizelge 1'de sunulmuştur. Altınova ve Gözlü bölgesindeki su ile doygunluk sirasiyla \% 48 ve 72 , EC 1.428 ve 0.861 , pH değerleri birbirine yakın ve yönünden Gözlü kireç yönünden daha fazla, Altınova'nın organik maddesi biraz daha yüksek bulunmuştur. Aylık ortalama sıcaklık, yağış ve nispi nem değerleri ise Çizelge 2'de verilmiştir. Bütün çeşitlerin çiçek rengi pembe renkli olduğundan değerlendirilmeye alınmamıştır.

Yaş ot verimi (kg/da): Altınova 2014 yılı korunga çeşitlerine ait yaş ot verimleri en düşük $1680.0 \mathrm{~kg}$ ile ve $2224.3 \mathrm{~kg} / \mathrm{da}$ arasında değişmiş olup sırasıyla Özerbey ve Koç 1461 çeşitlerinden elde edilmiştir. Yaş ot verimi ikinci yılda artarak aynı çeşitler verimleri sırasıyla $2328.8 \mathrm{~kg} / \mathrm{da}$ ile $3116.2 \mathrm{~kg} / \mathrm{da}$ arasında olmuştur. Gözlü 2014 y1lı yaş ot verimleri $1837.8 \mathrm{~kg} / \mathrm{da}$ ile 2321.0 $\mathrm{kg} / \mathrm{da}$, ikinci y1lda ise Emre ve Mehmetalibey çeşitlerinden en yüksek yaş ot verimi alınmış olup, bu yılda yaş ot verimleri 2298.5 ile $3115.2 \mathrm{~kg} / \mathrm{da}$ arasında olmuştur. Altınova ve Gözlü lokasyonlarında çeşitlerin yaş ot ortalaması sırasıyla $2342.7 \mathrm{~kg} / \mathrm{da}$ ile $2362.9 \mathrm{~kg} / \mathrm{da}$ arasında lokasyonlar önemli olmamıştır. 2015 yılı yaş ot verim $2702.3 \mathrm{~kg} / \mathrm{da}$ ile 2014 y1lı $2003.4 \mathrm{~kg} / \mathrm{da}$ veriminden yüksek ve önemli bulunmuştur. Yıllar ve lokasyonların ortalaması olarak en yüksek yaş ot verimi $2674.9 \mathrm{~kg} / \mathrm{da}$ ile Emre çeşidinden, en düşük verim ise $2077.3 \mathrm{~kg} / \mathrm{da}$ ile Özerbey çeşidinden elde edilmiştir.

Kuru ot verimleri (kg/da): Altınova 2014 yılık kuru ot verimleri $420.1 \mathrm{~kg} / \mathrm{da}$ ile $544.9 \mathrm{~kg} / \mathrm{da}$ arasında değişmiş olup en yüksek değerlen Koç 1461, Emre ve Hilal çeşitlerinden elde edilmiştir. İkinci yılda ise verimler $512.3 \mathrm{~kg} / \mathrm{da}$ ile $716.7 \mathrm{~kg} / \mathrm{da}$ arasinda ve bu yılda en düşük verim Özerbey çeşidinden alınmış, Koç 1461,
Emre ve Hilal ise en yüksek verim grubunda yer almıştır.

Gözlü 2014 yılı kuru ot verimleri bakımından Koç 1461 ve Emre diğerlerinden yüksek, ikinci yılda ise Koç 1461ve Mehmetalibey en yüksek verim grubunda yer almıştır. Gözlü lokasyonunun kuru ot verimi (539.8 $\mathrm{kg} / \mathrm{da})$ Altınova'dan (482.3 kg/da) yüksek ve önemli, 2015 y1lı kuru ot verimi $(549.3 \mathrm{~kg} / \mathrm{da}) 2014$ yılı kuru ot veriminden $(475.8 \mathrm{~kg} / \mathrm{da})$ yüksek ve önemli bulunmuştur. Yıllar ve lokasyonların ortalaması olarak en yüksek kuru ot verimi 575.1 ile $564.1 \mathrm{~kg} / \mathrm{da}$ verim Emre ve Koç

1461 çeşidinden, en düşük verim ise $534.5 \mathrm{~kg} / \mathrm{da}$ ile Özerbey çeşidinden elde edilmiştir.

Çiçeklenme gün sayısı: Altınova'da 2014 yılında çeşitlerin çiçeklenme gün sayısı arasında çok az fark olmasına rağmen önemli bulunmuş ve en erken Koç 1461, 131 günde en geç ise Hilal, 138 gün arasında değişmiştir. 2015 yılında çiçeklenme gün sayısı en düşük 138.0 gün ile Koç 1461 'den en uzun 145.0 gün ile Özerbey çeşidinden sağlanmıştır. Gözlü' 2014 yılında çiçeklenme gün sayısı 131.0 ile 137 gün arasında değişmiş, Hilal çeşidi diğerlerinden daha uzun çiçeklenen çeşit olmuştur. 2015 yılında en düşük 138.0 gün ile Fatih çeşidinden, Hilal ise en geç çiçeklenen çeşit olmuştur. Ortalamaya göre çeşitler arasında çiçeklenme gün sayısı en düşük 135.0 gün ile Koç 1461 ve Fatih çeşitlerinden, Hilal en uzun gün çiçeklenen çeşit olmuştur.

Ana Sap Uzunluğu (cm): Ana sap uzunluğu bakımından Hilal, Fatih ve Emre en yüksek boya olan çeşitleri olmuş, 2015 yılına ise ana sap uzunluğu 95.7 $\mathrm{cm}$ ile $104.5 \mathrm{~cm}$ arasında değişmiştir. Gözlü 2014 yılında sap uzunluğu $85.0 \mathrm{~cm}$ ile $96.8 \mathrm{~cm}$ arasında değişerek önemli, 2015 yılında Koç 1461 ve Hilal çeşitleri en üst grupta bulunmuştur. Ortalamaya göre Koç 1461 çeşidi en yüksek ana sap uzunluğu $(96.0 \mathrm{~cm})$ ile en yüksek değere, Özerbey ve Mehmetalibey çeşitleri boy bakımında en düşük grupta yer almıştır.

Ana Sap Kalınlı̆̆ $(\mathbf{m m})$ : Altınova lokasyonunun birinci yılında çeşitlerin ana sap kalınlığı 6.0 ile $6.9 \mathrm{~mm}$ arasında; ikinci yılda $5.8 \mathrm{~mm}$ ile $6.0 \mathrm{~mm}$ olup her iki yılda bu özellik bakımından çeşitler istatistiksel olarak önemli bulunmamıştır. Gözde 2014 yılında ise ana sap kalınlığı 5.8 ile $6.5 \mathrm{~mm}$ arasında, 2015 yılında Özerbey çeşidi $5.3 \mathrm{~mm}$ ana sap kalınlığı bakımından diğer gruptan düşük bulunmuştur hemen bütün çeşitleri iki grup oluşturarak ile $5.3 \mathrm{~mm}$ ile $6.8 \mathrm{~mm}$ arasında değişmiştir. $\mathrm{Bu}$ özellik bakımından çeşitler iki grup oluşturmuştur. Ortalamaya göre $5.7 \mathrm{~mm}$ değer ile Özerbey diğer çeşitlerden düşük bulunmuştur.

Ana Sap Sayısı: Altınova 2014 yılında çeşitlerin ana sap sayısı 11.3 ile 14 arasında önemsiz, 2015 yılında ise 18.0 ile 22.0 arasında değişerek önemli bulunmuştur. Gözlüde birinci yılda 12.8 ile 16.7 arasında, 2015 yılı 17.0 ile 23.5 arasında değişerek çeşitler önemli bulunmuştur. Ortalamaya göre çeşitlerin ana sap sayısı 15.0 ile 18.0 adet arasında, en yüksek Hilal, Mehmetalibey, Emre çeşitleri olmuştur. 
Çizelge 3. Altınova korunganın verim ve bazı tarımsal özellikleri (2014), Hasat Tarihi:22.5.2015

\begin{tabular}{|c|c|c|c|c|c|c|c|c|c|}
\hline Çeşitler & $\begin{array}{l}\text { Yeşil Ot } \\
\text { Verimi } \\
(\mathrm{kg} / \mathrm{da})\end{array}$ & $\begin{array}{l}\text { Kuru Ot } \\
\text { Verimi } \\
\text { (kg/da) }\end{array}$ & $\begin{array}{l}\text { Çiçeklenme } \\
\text { Gün Sayıs1 } \\
\text { (gün) }\end{array}$ & $\begin{array}{l}\text { Ana Sap } \\
\text { Uzunluğu } \\
(\mathrm{cm})\end{array}$ & $\begin{array}{l}\text { Ana Sap } \\
\text { Kalınlığ } 1 \\
(\mathrm{~mm})\end{array}$ & $\begin{array}{l}\text { Ana Sap } \\
\text { Say1s1 } \\
\text { (adet) }\end{array}$ & $\begin{array}{l}\text { Yatma } \\
\text { Durumu } \\
(1-5)^{*}\end{array}$ & $\begin{array}{l}\text { Seyrekleşme } \\
\text { Oranı }(\%)\end{array}$ & $\begin{array}{l}\text { Kışa } \\
\text { Dayanıklılık } \\
(\%)\end{array}$ \\
\hline Koç, 1461 & $2224.3 \mathrm{a}$ & $544.9 \mathrm{a}$ & $131 \mathrm{~g}$ & $89.3 \mathrm{~b}$ & 6.8 & $13.5 \mathrm{a}$ & $2.0 \mathrm{~b}$ & $13.5 \mathrm{~cd}$ & $94.3 \mathrm{ab}$ \\
\hline Emre & $2217.1 \mathrm{a}$ & $536.5 \mathrm{a}$ & $134 \mathrm{e}$ & $93.5 \mathrm{a}$ & 6.9 & $14.0 \mathrm{a}$ & $2.0 \mathrm{~b}$ & $13.0 \mathrm{~d}$ & $94.0 \mathrm{ab}$ \\
\hline Lütfübey & $1858.4 \mathrm{c}$ & $464.0 \mathrm{~b}$ & $136 \mathrm{c}$ & $86.3 \mathrm{c}$ & 6.8 & $11.8 \mathrm{c}$ & $3.0 \mathrm{a}$ & $15.5 \mathrm{ab}$ & $93.0 \mathrm{bc}$ \\
\hline Yunus & $1827.0 \mathrm{c}$ & $442.2 \mathrm{bc}$ & $135 \mathrm{~d}$ & $89.5 \mathrm{~b}$ & 6.5 & $12.5 \mathrm{ab}$ & $2.0 \mathrm{~b}$ & $15.5 \mathrm{ab}$ & $95.0 \mathrm{a}$ \\
\hline Fatih & $1949.3 \mathrm{bc}$ & $471.4 \mathrm{~b}$ & $132 \mathrm{f}$ & $92.7 \mathrm{a}$ & 6.3 & $12.8 \mathrm{ab}$ & $2.0 \mathrm{~b}$ & $13.8 \mathrm{bcd}$ & $14.0 \mathrm{ab}$ \\
\hline Özerbey & $1680.0 \mathrm{~d}$ & $420.1 \mathrm{c}$ & $137 \mathrm{~b}$ & $86.5 \mathrm{c}$ & 6.3 & $11.5 \mathrm{~b}$ & $1.0 \mathrm{c}$ & $16.8 \mathrm{a}$ & $92.0 \mathrm{c}$ \\
\hline Mehmetalibey & $1818.2 \mathrm{c}$ & $458.9 \mathrm{~b}$ & $135 \mathrm{~d}$ & $85.0 \mathrm{c}$ & 6.3 & $11.3 \mathrm{~b}$ & $1.0 \mathrm{c}$ & $13.3 \mathrm{abc}$ & $92.0 \mathrm{c}$ \\
\hline Hilal & $2000.0 \mathrm{~b}$ & $520.1 \mathrm{a}$ & $138 \mathrm{a}$ & $94.0 \mathrm{a}$ & 6.0 & $12.5 \mathrm{ab}$ & $1.0 \mathrm{c}$ & $14.5 \mathrm{bcd}$ & $93.0 \mathrm{bc}$ \\
\hline
\end{tabular}

(*) 1=dik. 2=yarı dik. 3=orta. 4=yarı yatık. 5=yatık; Aynı sütunda farklı harflerle gösterilen ortalamalar arasındaki farklılıklar önemlidir

Çizelge 4. Altınova lokasyonunda korunganın verim ve bazı tarımsal özellikleri (2015), Hasat Tarihi:22.5.2015

\begin{tabular}{|l|l|l|l|l|l|l|l|l|l|}
\hline Çeşitler & $\begin{array}{l}\text { Yeşil Ot } \\
\text { Verimi } \\
(\mathrm{kg} / \mathrm{da})\end{array}$ & $\begin{array}{l}\text { Kuru Ot } \\
\text { Verimi } \\
(\mathrm{kg} / \mathrm{da})\end{array}$ & $\begin{array}{l}\text { Ççeklenme } \\
\text { Gün Sayıs } \\
(\text { gün })\end{array}$ & $\begin{array}{l}\text { Ana Sap } \\
\text { Uzunluğu } \\
(\mathrm{cm})\end{array}$ & $\begin{array}{l}\text { Ana Sap } \\
\text { Kalınlığ1 } \\
(\mathrm{mm})\end{array}$ & $\begin{array}{l}\text { Ana Sap } \\
\text { Sayıs1 } \\
(\mathrm{adet})\end{array}$ & $\begin{array}{l}\text { Yatma } \\
\text { Durumu } \\
(1-5)^{*}\end{array}$ & $\begin{array}{l}\text { Seyrekleşme } \\
\text { Oran1 }(\%)\end{array}$ & $\begin{array}{l}\text { Kişa } \\
\text { Dayanıklılık }(\%)\end{array}$ \\
\hline Koç, 1461 & $3116.2 \mathrm{a}$ & $716.7 \mathrm{a}$ & $138.0 \mathrm{f}$ & $98.8 \mathrm{~b}$ & 5.5 & $19.5 \mathrm{bc}$ & $2.0 \mathrm{~b}$ & $25.0 \mathrm{bc}$ & $95.0 \mathrm{a}$ \\
\hline Emre & $3045.5 \mathrm{a}$ & $700.3 \mathrm{a}$ & $141.0 \mathrm{~d}$ & $104.0 \mathrm{a}$ & 5.7 & $21.5 \mathrm{ab}$ & $2.0 \mathrm{~b}$ & $25.0 \mathrm{bc}$ & $93.5 \mathrm{a}$ \\
\hline Lütfübey & $2564.8 \mathrm{~d}$ & $589.9 \mathrm{c}$ & $143.0 \mathrm{~b}$ & $96.3 \mathrm{~b}$ & 5.7 & $18.0 \mathrm{c}$ & $3.0 \mathrm{a}$ & $27.8 \mathrm{a}$ & $93.5 \mathrm{~b}$ \\
\hline Yunus & $2531.3 \mathrm{~d}$ & $607.5 \mathrm{bc}$ & $142.0 \mathrm{c}$ & $102.8 \mathrm{a}$ & 6.0 & $18.5 \mathrm{c}$ & $2.0 \mathrm{~b}$ & $26.7 \mathrm{ab}$ & $95.0 \mathrm{a}$ \\
\hline Fatih & $2764.8 \mathrm{~cd}$ & $635.9 \mathrm{~b}$ & $139.0 \mathrm{e}$ & $104.5 \mathrm{a}$ & 5.5 & $21.7 \mathrm{ab}$ & $2.0 \mathrm{~b}$ & $26.0 \mathrm{abc}$ & $93.5 \mathrm{~b}$ \\
\hline Özerbey & $2328.8 \mathrm{e}$ & $512.3 \mathrm{~d}$ & $145.0 \mathrm{a}$ & $95.7 \mathrm{~b}$ & 6.0 & $18.0 \mathrm{c}$ & $1.0 \mathrm{c}$ & $27.8 \mathrm{a}$ & $92.0 \mathrm{c}$ \\
\hline Mehmetalibey & $2619.6 \mathrm{~cd}$ & $602.5 \mathrm{bc}$ & $142.0 \mathrm{c}$ & $95.7 \mathrm{~b}$ & 6.3 & $19.5 \mathrm{bc}$ & $1.0 \mathrm{c}$ & $25.0 \mathrm{bc}$ & $91.5 \mathrm{c}$ \\
\hline Hilal & $2938.8 \mathrm{ab}$ & $705.3 \mathrm{a}$ & $145.0 \mathrm{a}$ & $104.5 \mathrm{a}$ & 5.8 & $22.0 \mathrm{a}$ & $1.0 \mathrm{c}$ & $24.3 \mathrm{c}$ & $93.5 \mathrm{~b}$ \\
\hline
\end{tabular}

(*) 1=dik. 2=yarı dik. 3=orta. 4=yarı yatık. 5=yatık; Aynı sütunda farklı harflerle gösterilen ortalamalar arasındaki farklılıklar önemlidir

Çizelge 5. Gözlü lokasyonunda korunganın verim ve bazı tarımsal özellikleri (2014). Hasat Tarihi:25.8.2014

\begin{tabular}{|l|l|l|l|l|l|l|l|l|l|}
\hline Çeşitler & $\begin{array}{l}\text { Yeşil Ot } \\
\text { Verimi } \\
(\mathrm{kg} / \mathrm{da})\end{array}$ & $\begin{array}{l}\text { Kuru Ot } \\
\text { Verimi } \\
\mathrm{kg} / \mathrm{da})\end{array}$ & $\begin{array}{l}\text { Çiçeklenme } \\
\text { Gün Sayıs } \\
\text { (gün })\end{array}$ & $\begin{array}{l}\text { Ana Sap } \\
\text { Uzunluğu } \\
(\mathrm{cm})\end{array}$ & $\begin{array}{l}\text { Ana Sap } \\
\text { Kalınlığ1 } \\
(\mathrm{mm})\end{array}$ & $\begin{array}{l}\text { Ana Sap } \\
\text { Sayıs1 } \\
(\mathrm{adet})\end{array}$ & $\begin{array}{l}\text { Yatma } \\
\text { Durumu } \\
(1-5)^{*}\end{array}$ & $\begin{array}{l}\text { Seyrekleşe Oran1 } \\
\text { (\%) }\end{array}$ & $\begin{array}{l}\text { Kişa } \\
\text { Dayanıklilik } \\
(\%)\end{array}$ \\
\hline Koç, 1461 & $2214.2 \mathrm{ab}$ & $531.4 \mathrm{a}$ & $132.0 \mathrm{f}$ & $96.0 \mathrm{a}$ & $6.3 \mathrm{ab}$ & $12.8 \mathrm{~cd}$ & $2.0 \mathrm{~b}$ & $13.3 \mathrm{c}$ & $96.0 \mathrm{a}$ \\
\hline Emre & $2321.0 \mathrm{a}$ & $510.8 \mathrm{a}$ & $133.0 \mathrm{e}$ & $92.5 \mathrm{~b}$ & $6.5 \mathrm{a}$ & $13.5 \mathrm{c}$ & $2.0 \mathrm{~b}$ & $13.0 \mathrm{c}$ & $96.0 \mathrm{a}$ \\
\hline Lütfübey & $1974.9 \mathrm{a}$ & $417.6 \mathrm{c}$ & $135.0 \mathrm{c}$ & $85.5 \mathrm{~d}$ & $6.5 \mathrm{a}$ & $15.3 \mathrm{~b}$ & $3.0 \mathrm{a}$ & $15.5 \mathrm{~b}$ & $93.5 \mathrm{~cd}$ \\
\hline Yunus & $2104.4 \mathrm{~cd}$ & $463.8 \mathrm{~b}$ & $134.0 \mathrm{~d}$ & $92.0 \mathrm{~b}$ & $6.3 \mathrm{ab}$ & $12.0 \mathrm{~d}$ & $2.0 \mathrm{~b}$ & $14.0 \mathrm{c}$ & $94.0 \mathrm{c}$ \\
\hline Fatih & $1887.3 \mathrm{de}$ & $434.0 \mathrm{bc}$ & $131.0 \mathrm{~g}$ & $87.0 \mathrm{c}$ & $6.5 \mathrm{a}$ & $13.8 \mathrm{c}$ & $2.0 \mathrm{~b}$ & $16.8 \mathrm{a}$ & $95.0 \mathrm{~b}$ \\
\hline Özerbey & $1837.8 \mathrm{e}$ & $446.0 \mathrm{bc}$ & $136.0 \mathrm{~b}$ & $85.0 \mathrm{~d}$ & $5.5 \mathrm{~b}$ & $15.8 \mathrm{ab}$ & $1.0 \mathrm{c}$ & $14.0 \mathrm{c}$ & $95.0 \mathrm{~b}$ \\
\hline Mehmetalibey & $2043.9 \mathrm{c}$ & $459.9 \mathrm{~b}$ & $136.0 \mathrm{~b}$ & $85.3 \mathrm{~d}$ & $6.3 \mathrm{ab}$ & $15.3 \mathrm{~b}$ & $1.0 \mathrm{c}$ & $15.3 \mathrm{~b}$ & $95.0 \mathrm{~b}$ \\
\hline Hilal & $2096.0 \mathrm{bc}$ & $443.7 \mathrm{bc}$ & $137.0 \mathrm{a}$ & $96.8 \mathrm{a}$ & $5.8 \mathrm{ab}$ & $16.7 \mathrm{a}$ & $1.0 \mathrm{c}$ & $14.0 \mathrm{c}$ & $96.0 \mathrm{a}$ \\
\hline
\end{tabular}

(*) 1=dik. 2=yarı dik. 3=orta. 4=yarı yatık. 5=yatık; Aynı sütunda farklı harflerle gösterilen ortalamalar arasındaki farklılıklar önemlidir

Yatma Durumu (1-5): Hem lokasyonlarda ve hem de ortalamada Lütfibey 1-5 skalasina öre 3 puan ile yarı yatık form göstermiştir, Özerbey, Mehmetalibey ve Hilal dik gelişen, diğer çeşitler ise yarı yatık form özelliği göstermiştir

Seyrekleşme Oranı (\%): Altınova birinci yılında çeşitlerin seyrekleşme oranın \% 11.3 ile \%16.8 arasında değişmiş ve ikinci yılda seyrekleşme biraz daha artarak $\% 24.3$ ile \%27.8 arasında ve önemli olmuştur. Gözlüde
2014 yılı seyrekleşme oranı \%13.0 ile \%16.8 arasında, 2015 yılı seyrekleşme oranı \%23.7 ile 26.7arasında, ortalamada ise seyrekleşme oranı \%18.9 ile \%21 arasında değişmiş olup, Lütfübey, Yunus,Fatih ve Özerbey daha çok seyrekleşen çeşitler olmuştur.

Kışa Dayanıklılık (\%): Altınova 2014 yılında korunga çeşitlerin kışa dayanıklılık yönünden \% 95 oranı ile Yunus diğer çeşitlerden daha yüksek bulunmuştur. 2015 yılında kışa dayanıklılık yönünden \%91.5 ile 
Mehmetalibey çeşidinden en düşük bulunmuştur. Gözlü’de 2014 yılında kışa dayanıklılık yönünden çeşitler birbirine çok yakın, 2015 yilında \% 93.0 ile \% 96.0 arasında olup önemli bulunmuştur. Ortalama değerlere göre kışa dayanıklılık yönünden en yüksek oran \% 95.3 le Koç 1461 den, en düşük değer ise Cizelge 6. Gözlü lokasyonunda korunganın verim ve bazı
Mehmetalibey çeşidi olmuştur. Denemesin sonuçlarına göre, ana sap uzunluğu üzerinde lokasyon, y1l x çeşit interaksiyonu önemsiz, yaş ve kuru ot verimleri dahil diğer bütün tarımsal karakterler üzerinde y1l, y1l x lokasyon, lokasyon $\mathrm{x}$ çeşit, y1l x çeşit, y1l x lokasyon x çeşit interaksiyonları çok önemli bulunmuştur. arımsal özellikleri (2015). Hasat Tarihi:22.5.2015

\begin{tabular}{|c|c|c|c|c|c|c|c|c|c|}
\hline Çeşitler & $\begin{array}{l}\text { Yeşil Ot } \\
\text { Verimi } \\
(\mathrm{kg} / \mathrm{da})\end{array}$ & $\begin{array}{c}\text { Kuru Ot } \\
\text { Verimi } \\
(\mathrm{kg} / \mathrm{da})\end{array}$ & $\begin{array}{c}\text { Çiçeklenme } \\
\text { Gün Sayısı } \\
\text { (gün) }\end{array}$ & $\begin{array}{l}\text { Ana Sap } \\
\text { Uzunluğu } \\
(\mathrm{cm})\end{array}$ & $\begin{array}{c}\text { Ana Sap } \\
\text { Kalınlığ } 1 \\
(\mathrm{~mm})\end{array}$ & $\begin{array}{c}\text { Ana Sap } \\
\text { Say1s1 } \\
\text { (adet) }\end{array}$ & $\begin{array}{c}\text { Yatma } \\
\text { Durumu } \\
(1-5)^{*}\end{array}$ & $\begin{array}{c}\text { Seyrekleşme } \\
\text { Oran1 } \\
(\%)\end{array}$ & $\begin{array}{c}\text { Kışa } \\
\text { Dayanıklılık } \\
(\%)\end{array}$ \\
\hline Koç, 1461 & $2761.3 \mathrm{~b}$ & $635.1 \mathrm{c}$ & $139.0 \mathrm{e}$ & $106.5 \mathrm{a}$ & $6.3 \mathrm{a}$ & $22.5 \mathrm{a}$ & $2.0 \mathrm{~b}$ & $24.3 \mathrm{~b}$ & $96.0 \mathrm{a}$ \\
\hline Emre & $3115.2 \mathrm{a}$ & $716.5 \mathrm{a}$ & $140.0 \mathrm{~d}$ & $102.8 \mathrm{~b}$ & $6.8 \mathrm{a}$ & $20.5 \mathrm{~b}$ & $2.0 \mathrm{~b}$ & $24.5 \mathrm{~b}$ & $95.0 \mathrm{ab}$ \\
\hline Lütfübey & $2484.4 \mathrm{c}$ & $571.4 \mathrm{~d}$ & $142.0 \mathrm{~b}$ & $95.0 \mathrm{e}$ & $6.3 \mathrm{a}$ & $18.3 \mathrm{c}$ & $3.0 \mathrm{a}$ & $26.5 \mathrm{a}$ & $94.0 \mathrm{bcd}$ \\
\hline Yunus & $2298.5 \mathrm{~d}$ & $551.6 \mathrm{~cd}$ & $141.0 \mathrm{c}$ & $101.0 \mathrm{c}$ & $6.5 \mathrm{a}$ & $17.0 \mathrm{c}$ & $2.0 \mathrm{~b}$ & $26.5 \mathrm{a}$ & $93.5 \mathrm{~cd}$ \\
\hline Fatih & $2496.6 \mathrm{c}$ & $574.2 \mathrm{~d}$ & $138.0 \mathrm{f}$ & $97.0 \mathrm{~d}$ & $6.3 \mathrm{a}$ & $18.3 \mathrm{c}$ & $2.0 \mathrm{~b}$ & $26.3 \mathrm{a}$ & $95.0 \mathrm{ab}$ \\
\hline Özerbey & $2462.6 \mathrm{~cd}$ & $541.8 \mathrm{~d}$ & $143.0 \mathrm{a}$ & $95.0 \mathrm{e}$ & $5.3 \mathrm{~b}$ & $17.3 \mathrm{c}$ & $1.0 \mathrm{c}$ & $26.7 \mathrm{a}$ & 93.0d \\
\hline Mehmetalibey & $2778.2 \mathrm{a}$ & $684.9 \mathrm{ab}$ & $141.0 \mathrm{c}$ & $96.0 \mathrm{de}$ & $6.5 \mathrm{a}$ & $23.5 \mathrm{a}$ & $1.0 \mathrm{c}$ & $23.7 \mathrm{~b}$ & $95.0 \mathrm{ab}$ \\
\hline Hilal & $2728.7 \mathrm{~b}$ & $654.9 \mathrm{bc}$ & $143.0 \mathrm{a}$ & $107.8 \mathrm{a}$ & $6.5 \mathrm{a}$ & $20.7 \mathrm{~b}$ & $1.0 \mathrm{c}$ & $24.5 \mathrm{~b}$ & 94.8 abc \\
\hline
\end{tabular}

(*) 1=dik. 2=yarı dik. 3=orta. 4=yarı yatık. 5=yatık; Aynı sütunda farklı harflerle gösterilen ortalamalar arasındaki farkl1lıklar önemlidir

Cizelge 7. Yıllar ve lokasyonların ortalaması olarak korunganın verim ve bazı tarımsal özellikleri (2014-2015)

\begin{tabular}{|c|c|c|c|c|c|c|c|c|c|}
\hline Çeşitler & $\begin{array}{l}\text { Yeşil Ot } \\
\text { Verimi } \\
(\mathrm{kg} / \mathrm{da})\end{array}$ & $\begin{array}{r}\text { Kuru Ot } \\
\text { Verimi } \\
(\mathrm{kg} / \mathrm{da})\end{array}$ & $\begin{array}{c}\text { Çiçeklenme } \\
\text { Gün Sayısı } \\
\text { (gün) }\end{array}$ & $\begin{array}{l}\text { Ana Sap } \\
\text { Uzunluğu } \\
(\mathrm{cm})\end{array}$ & $\begin{array}{c}\text { Ana Sap } \\
\text { Kalınlığ } 1 \\
(\mathrm{~mm})\end{array}$ & $\begin{array}{l}\text { Ana Sap } \\
\text { Say1sı } \\
\text { (adet) }\end{array}$ & \begin{tabular}{|c|} 
Yatma \\
Durumu \\
$(1-5)^{*}$
\end{tabular} & $\begin{array}{c}\text { Seyrekleşme } \\
\text { Oranı }(\%)\end{array}$ & $\begin{array}{l}\text { Kışa } \\
\text { Dayanıklılık } \\
(\%)\end{array}$ \\
\hline Koç, 1461 & $2579.0 \mathrm{~b}$ & $564.1 \mathrm{a}$ & $135.0 \mathrm{~g}$ & $97.6 \mathrm{~b}$ & $6.1 \mathrm{a}$ & $17.1 \mathrm{~b}$ & $2.0 \mathrm{~b}$ & $19.0 \mathrm{c}$ & $95.3 \mathrm{a}$ \\
\hline Emre & $2674.9 \mathrm{a}$ & $575.1 \mathrm{a}$ & $137.0 \mathrm{f}$ & $98.2 \mathrm{~b}$ & $6.4 \mathrm{a}$ & $17.4 \mathrm{ab}$ & $2.0 \mathrm{~b}$ & $18.9 \mathrm{c}$ & $94.6 \mathrm{~b}$ \\
\hline Lütfübey & $2222.6 \mathrm{ef}$ & $479.6 \mathrm{~d}$ & $139.0 \mathrm{c}$ & $90.6 \mathrm{~d}$ & $6.3 \mathrm{a}$ & $15.0 \mathrm{c}$ & $3.0 \mathrm{a}$ & $21.3 \mathrm{a}$ & $93.4 \mathrm{c}$ \\
\hline Yunus & $2190.3 \mathrm{f}$ & $474.9 \mathrm{~d}$ & $138.0 \mathrm{e}$ & $96.3 \mathrm{c}$ & $6.2 \mathrm{a}$ & $15.8 \mathrm{c}$ & $2.0 \mathrm{~b}$ & $20.7 \mathrm{a}$ & $94.4 \mathrm{~b}$ \\
\hline Fatih & $2274.5 \mathrm{e}$ & $487.8 \mathrm{~d}$ & $135.0 \mathrm{~g}$ & $95.3 \mathrm{c}$ & $6.3 \mathrm{a}$ & $16.6 \mathrm{~b}$ & $2.0 \mathrm{~b}$ & $20.7 \mathrm{a}$ & $94.4 \mathrm{~b}$ \\
\hline Özerbey & $2077.3 \mathrm{~g}$ & $456.9 \mathrm{e}$ & $140.3 \mathrm{~b}$ & $90.5 \mathrm{~d}$ & $5.7 \mathrm{~b}$ & $15.6 \mathrm{c}$ & $1.0 \mathrm{c}$ & $21.3 \mathrm{a}$ & $92.5 \mathrm{~d}$ \\
\hline Mehmetalibey & $2364.9 \mathrm{~d}$ & $515.7 \mathrm{c}$ & $138.5 \mathrm{~d}$ & $90.5 \mathrm{~d}$ & $6.3 \mathrm{a}$ & $17.4 \mathrm{ab}$ & $1.0 \mathrm{c}$ & $19.8 \mathrm{~b}$ & $93.4 \mathrm{c}$ \\
\hline Hilal & $2440.9 \mathrm{c}$ & $534.5 \mathrm{~b}$ & $140.8 \mathrm{a}$ & $100.8 \mathrm{a}$ & $6.2 \mathrm{a}$ & $18.0 \mathrm{a}$ & $1.0 \mathrm{c}$ & $19.3 \mathrm{bc}$ & $94.3 \mathrm{~b}$ \\
\hline \multicolumn{10}{|c|}{ P değerleri } \\
\hline Y1l & $<0.0001$ & 0.3362 & $<0.0001$ & $<0.0001$ & 0.0055 & $<0.0001$ & $<0.0001$ & $<0.0001$ & 0.4360 \\
\hline Lokasyon & 0.2703 & $<0.0001$ & $<0.0001$ & 0.7285 & 0.2447 & $<0.0001$ & $<0.0001$ & 0.0310 & 0.0001 \\
\hline $\mathrm{Y}_{11} * \mathrm{~L}$ & $<0.0001$ & $<0.0001$ & $<0.0001$ & 0.3555 & 0.0002 & $<0.0001$ & $<0.0001$ & 0.4017 & 0.3171 \\
\hline Çeşit & $<0.0001$ & $<0.0001$ & $<0.0001$ & $<0.0001$ & 0.0115 & $<0.0001$ & $<0.0001$ & 0.0001 & 0.0001 \\
\hline L x Çeşit & $<0.0001$ & $<0.0001$ & $<0.0001$ & $<0.0001$ & 0.1376 & $<0.0001$ & $<0.0001$ & 0.0023 & 0.0001 \\
\hline Y11 x Çeşit & $<0.0001$ & $<0.0001$ & $<0.0001$ & 0.8543 & 0.4016 & $<0.0001$ & $<0.0001$ & 0.0021 & 0.3042 \\
\hline Y11 x L x Ç & 0.0007 & $<0.0001$ & $<0.0001$ & 0.2623 & 0.1376 & $<0.0001$ & $<0.0001$ & 0.0601 & 0.4902 \\
\hline
\end{tabular}

(*) 1=dik. 2=yarı dik. 3=orta. 4=yarı yatık. 5=yatı; Aynı sütunda farklı harflerle gösterilen ortalamalar arasındaki farklılıklar önemlidir

Altınova ve Gözlü gibi iki ayrı yerde ve eşzamanlı kurulan denemenin sonuçları karşılaştırıldığında yeni ıslah edilen çeşitler ile kontrol olarak kullanılan korunga çeşitleri arasında önemli verim ve tarımsal özellikler tespit edilmiştir. Lokasyonlar içerisinde yaş ot verimi bakımından çeşitler farklı gruplara girmesine karşılık Altınova ve Gözlü'de çeşitlerin yaş ot ortalaması sırasıyla $2342.7 \mathrm{~kg} / \mathrm{da}$ ile $2362.9 \mathrm{~kg} / \mathrm{da}$ olarak bulunmuş ve istatistiksel olarak önemli olmamıştır. Ortalama değerlere göre en yüksek yaș ot verimi $2674.9 \mathrm{~kg} / \mathrm{da}$ ile 7 klonlu Emre çeşidinden alınmış olup ve kontrol çeşidi olarak kullanılan Özerbey çeşidinden yaklaşı $600 \mathrm{~kg}$ daha yüksek bulunmuştur. Kuru ot verimleri bakımından, Altınova'da en yüksek verimler Koç 1461, Emre ve Hilal çeşitlerinden elde edilmiş olup Gözlü'de kuru ot verimi $(539.8 \mathrm{~kg} / \mathrm{da})$ Altınova'dan $(482.3 \mathrm{~kg} / \mathrm{da})$ yüksek ve önemli olması kısmen toprak farklılı̆̆ından ve çeşitlerin kuru ot oranı bakımından farklı olabileceğini göstermiş, Emre ve Koç 1461 çeşitleri standart çeşitlerden Özerbey'den yüksek bulunmuştur. Çiçeklenme gün sayısı bakımından gerek yerlerin ve gerek yıllar arasında yaklaşık bir hafta kadar bir periyod 
ortaya çıkarak en erken çiçeklenen Koç 1461 ve Fatih, Hilal çeşidi ise en uzun gün çiçeklenen çeşit olmuştur. $\mathrm{Bu}$ durum çeşitlerin genetik yapısı ile beraber ekolojik koşulların farklılığından kaynaklanmış olabilir. Ana sap uzunluğu, iki yılın ortalamasına göre Koç 1461 çeşidi en yüksek ana sap uzunluğu $(96.0 \mathrm{~cm})$ ile en yüksek değere, Özerbey ve Mehmetalibey çeşitleri boy bakımında en düşük grupta yer almıştır. Ana sap kalınlığ 1 bakımından çeşitler iki grup oluşturmuş ve ortalamaya göre ile Özerbey çeşidi $5.7 \mathrm{~mm}$ değer diğer çeşitlerinden düşük bulunmuştur. Ana sap sayısı, ortalamaya göre 15.0 ile 18.0 adet, Hilal, Mehmetalibey ve Emre çeşitleri en yüksek grupta olup çeşitlerin ikinci y1ldaki ana sap değerleri birinci yıla göre daha fazla olmuştur. Yatma Durumu göre, Özerbey, Mehmetalibey, Hilal çeşitleri dik gelişen, Lütfibey yarı yatık ve diğer çeşitler ise yatık form özelliği göstermiş olup genetik yapı ile beraber çevre koşullarına bağ $l_{1}$ olarak değişebileceğini söylemek mümkündür. Seyrekleşme oranı bakımından Lütfübey, Yunus, Fatih ve Özerbey çeşitleri daha çok seyrekleşen çeşitler olup, korunga genelde çok yıllık ve kısa ömürlü olması hemen ikici yılda kendini göstermeye başlamıştır. Kışa Dayanıklılık yönünden çeşit ve lokasyonlarda bazı farklılıklar ortaya çıkmış ve ortalama değerlere göre Koç 1461 diğer çeşitlerden daha dayanaklı olduğu ve Mehmetalibey çeşidinin dayanıklılığı ise düşük bulunmuştur. Araştırma sonuçlarına göre, gerek çeşitlerin verimi ve gerekse tarımsal özellikleri üzerine yılların ve lokasyonların etkileri farklı olmuştur. Korunga çeşitlerinin ana sap uzunluğu lokasyon ve yıl x çeşit interaksiyonu, ana sap kalınlığ interaksiyonu, seyrekleşme oranı üzerine yıl x lokasyon, kışa dayanıklılık yönünden ise yıl ve yıl $x$ lokasyon $x$ çeşit interaksiyonları önemsiz bulunmuştur. Çeşitlerin tarımsal karakterleri dahil yaş ve kuru ot verimleri y1l, yıl x lokasyon, lokasyon $\mathrm{x}$ çeşit, yıl $\mathrm{x}$ çeşit, yıl $\mathrm{x}$ lokasyon $\mathrm{x}$ çeşit interaksiyonları çok önemli derecede etkilemiştir.Ülkemizin farklı bölgelerinde ve değişik zamanlarda çok sayıda çalışmalar yapılmıştır. Bu araştırmadan elde edilen 456.9-564.1 kg/da kuru ot verimleri, çayır mera ve yem bitkileri duayenlerinden olan Altın (1982) korungada en yüksek ot verimini ise $481.2 \mathrm{~kg} / \mathrm{da}$ ile kıraçta uygulanan serpme ekimden aldıklarını ve Akdeniz ve Andiç (1998), Van ekolojik koşullarında yapmış oldukları bir çalışmada, korunganın serpme, 30,45 ve $60 \mathrm{~cm}$ sira aralığına ekimlerinden sirasiyla $702.8,726.2,574.2$ ve 522.5 $\mathrm{kg} / \mathrm{da}$ kuru ot verimlerinden, 45 ve $60 \mathrm{~cm}$ sira aralığından elde ettikleri verimlerle oldukça uyumlu olduğunu, ayrıca Yılmaz ve ark. (1999), Van sulu koşullardan $972 \mathrm{~kg}$ kuru ot verimlerinden düşük, kıraç koşullarındaki kuru ot verimleri $526 \mathrm{~kg}$ uyumlu bulunmuştur. Tuna (1994), Tekirdağ koşullarında en yüksek kuru ot verimlerinin $903.2 \mathrm{~kg} / \mathrm{da}$ ile $30 \mathrm{~cm}$ sıra, en düşük değer ise $474.2 \mathrm{~kg} / \mathrm{da}$ ile $60 \mathrm{~cm}$ sira aralıklarından elde etmiş̧ir. Deniz ve ark. (2005), korunganın $\% 50$ ve $\% 100$ çiçeklenme döneminde yaş ot verimlerini sirasiyla 3473.3 ve 3840.0 , kuru ot verimleri ise 815.2 ile $1112.6 \mathrm{~kg} / \mathrm{da}$ olarak tespit etmiş̧lerdir biçim devrelerinin ilerlemesine bağlı olarak $\mathrm{NDF}, \mathrm{ADF}$ ve ADL değerleri artı̧̧ gösterdiğini ve organik madde sindirilebilirliği azalmasına rağmen birim alandan elde edilen kuru ot miktarındaki artışa bağlı olarak, sindirilebilir organik madde miktarının artı̆̆ııı belirtmişlerdir.

Çakal ve ark. (2005), bazı korunga hatlarının verim düzeylerinin yıllara ve çeşitlere bağlı olarak önemli derecede farkl1l1klar olduğunu en yüksek kurut ot veriminin $634 \mathrm{~kg} / \mathrm{da}$ olduğunu belirtmişlerdir. Temel (2010), korunga bitkisinin yeşil ot ve kuru ot veriminin, yetiştiriciliği yapılan bölgenin toprak yapısı ve yükseltisine bağlı olarak değiştiğini, $1475 \mathrm{~m}$ rakımda önemli oranda verim düşüklüğü olduğunu belirtmiştir. Stevovic ve ark. (2012), korunga çeşitlerinin 2. ve 3. yıllarda geniş sıra aralıklarında verimlerinin daha yüksek olduğunu ancak tohum verimi bakımından ise yıllara bağlı olarak bazı farklılıkların ortaya çıktığını, ot ve tohum verimi bakımından $50 \mathrm{~cm}$ sıra aralığının daha uygun olduğunu belirtmiştir. Parlak ve ark. (2014), Çanakkale doğal meralarından topladıkları Onobrychis caput-galli, Onobrychis gracilis, Onobrychis oxyodonta türlerinin morfolojik ve tarımsal özellikleri arasında geniş varyasyon olduğunu ve türlerin bitki boyu, ana dalda yan dal sayısı, ana dal çapı, ana dalda yaprak sayısı ve ana dalda salkım sayıları ile kuru madde verimleri arasında çok önemli ve olumlu korelasyon olduklarını, bazı yabani korunga türlerinin morfolojik ve agronomik özelliklerininim tarımsal açıdan önemli olduğunu vurgulamışlar. Mohajer ve ark. (2012), 72 korunga (Onobrychis viciafolia Scop) hattı üzerinde yaptıkları çalışmalarında, kutu ot verimi, yaprak/sap oranı, gelişme durumu, bitki boyu, çiçeklenme zamanı gibi tarımsal özellikleri arasında önemli farklılıkların olduğunu ve kuru madde verimi ile bitki boyu ve sap yoğunluğu arasında pozitif ve önemli ilişkinin olduğunu belirtmişlerdir. Çok sayıda bilimsel çalışmalarda farklı sonuçlar ortaya çıkmışıır. Korunga çok yıllık olmasına rağmen yoncadan daha erken seyrekleşmektedir. Birçok nedeni olmakla birlikte, Tamer ve ark. (1997), korunganın seyrekleşmesinde bitkiye özgü zararlıların olduğunu, özellikle, korungada kök içinde beslenen Bembecia copigera (Scopoli.)' nın önemli bir zararlı olduğu, ayrica Sphenoptera carceli Cast. and Groy.'nin de öneme haiz olduğu belirlenmiştir. Bununla birlikte korunganin zararlıs olan Bembecia scopigera (Scopoli)'nın zararı özellikle kıraç alanlarda daha fazla etkisini göstererek bitkilerin seyrekleşmesi soncunda verim azalmasına neden olduğunu bildirmektedirler (Özbek, 1989; Büyükburç ve ark. (1991). Haziri (2010) ise korunganın azot fiksasyon etkinliğinin yonca, ak üçgül ve kırmızı üçgül gibi baklagillerden daha düşük olduğunu, bu türler $1 \mathrm{~mol} \mathrm{~N}_{2}$ fikse edebilmek için 10 mol $\mathrm{CO}_{2}$ ihtiyaç duyarken Onobrychis viciifolia Scop., $20 \mathrm{~mol} \mathrm{CO}_{2}$ gerek duymaktadır. Korunganın gerek hastalık ve özellikle zararlılarının asimilasyon maddelerine ortak olması ve gerekse azot fiksasyon kapasitesinin düşük olması, çok yıllık bir yem bitkisi olmasına rağmen erken seyrekleşerek verim düşüklüğüne neden olmaktadır. 


\section{SONUC}

Yeni 1slah edilip tescil edilen korunga çeşitlerinin verim ve bazı tarımsal özellikleri kontrol çeşitlerine göre bazı üstünlükleri tespit edilmiş olup y1llara ve lokasyonlara bağlı olarak değişim göstermiştir. Çalışmanın iki yıllık sonuçlarına göre en yüksek kuru ot verimi TİGEM tarafından sentetik olarak sslah edilmiş Emre ve Koç 1461 çeşitlerinin verimleri kontrol olarak kullanılan Özerbey çeşidinden yüksek bulunmuştur. Çok yıllık kısa ömürlü olan korunga çeşitlerinin hastalık ve zararlıları ile birlikte yatma durumu, seyrekleşme ve kışa dayanıklılık bakımından takip edilerek ot ve tohum verimleri ile hayvan besleme açısından değerlendirilmesi faydalı olacaktır.

\section{KAYNAKLAR}

Akdeniz H, Andiç V 1998. Korunga ile karışıma giren kılçıksız brom ve mavi ayrığın değişik ekim şekillerindeki kuru ot ve ham protein verimleri, ham protein oranları ve karıșımların botanik kompozisyonları. Yüzüncü Yıl Üniv. Fen Bil. Enst. Tarla Bitk. Anabili Dalı, (Doktora Tezi).

Anonim 2014. Bitkisel Üretim İstatistikleri. http://tuikapp.tuik.gov.tr/

Anonim 2015. Bitkisel Üretim İstatistikleri. http://tuikapp.tuik.gov.tr/ (Erişim tarihi:25.07.2015).

Altın M 1982. Bazı Yem Bitkileri ile bunların karışımlarının değişik ekim şekillerindeki kuru ot ve ham protein verimleri, Türlerin Ham Protein Oranları ve Karışımlarının Botanik Kompozisyonlar1, I. Kuru Ot ve Ham Protein Verimleri, Doğa Dergisi 6, 2. 93 - 107.

Büyükburç U, Açıkgöz, Ekiz E, Karagüllü N 1991. Değişik kökenli kültür ve yabani korunga türlerinin tarımsal özellikleri üzerinde araştırmalar. Doğa-Tr. J. of Agriculture and Forestry15:35-45.

Çakal S, Şimșek U, Aksakal E, Özgöz MM 2005. Bazı korunga (Onobrychis sativa) Hatlarınınn verim ve verim unsurları yönünden karşılaştırılması. Türkiye VI. Tarla Bitkileri Kongresi. 5-9 Eylül, Cilt II. 767-772.

Delgado I, Salvia J, Buil I, Andrés C 2008. The agronomic variability of a collection of sainfoin accessions. Spanish Journal of Agricultural Research, 6(3), 401-407.

Deniz S, Akdeniz H, Avcı M, Kara MA 2005. Farklı Devrelerde Biçilen Korunganın Verim Potansiyeli ile Sindirilebilirlik ve Enerji Düzeylerinin İn Vivo ve Vitro Yöntemlerle Belirlenmesi" Vet. Bil. Derg. 21, 3-4:47-55, Selçuk Üniversitesi, Konya.

Dilera A, Koçyiğit R, Yanar M, Aydın R, Gülera O, Avcı M 2016. Erzurum ili Hınıs ilçesi sığırcılık işletmelerinde sığır besleme uygulamaları üzerine bir araştırma. Anadolu Tarım Bilim. Derg./Anadolu J Agr Sci, 31.
Elçi S 2005. Baklagil ve Buğdaygil Yem Bitkileri. Tarım ve Köy İşleri Bakanlığı, 486 s, Ankara.

Häring DA, Suter D, Amrhein N, Lüscher A 2007b. Biomass allocation is an important determinant of the tannin concentration in growing plants. Annals of Botany, 99, 111-120.

Haziri A 2011. The genus Onobrychis Miller (Fabaceae) in the flora of Macedonia. Research in Plant Biology, 1(1): 32-34.

Lu Y, Sun Y, Foo Y, McNabb WC, Molan AL 2000. Phenolic glycosides of forage legume Onobrychis viciifolia, Phytochemistry, 55:67-75.

Manga İ, Acar Z, Ayan İ 1995. Baklagil Yem bitkileri. Ondokuz Mayıs Üniversitesi, Ziraat Fakültesi Ders Notu, No:7 Samsun, 342.

Mohajer AA, Jafari RM, Bakruden AA 2012. Evolution of yield and morphological traits in 72 genotypes of Sainfoin (Onobrchis viciafolia Scop.) through factor Analysis. Legumes Res. 35 (2): 132-137.

Özbek H 1989. Tahıl, Sebze, Yem ve Endüstri Bitki Zararlıları. Atatürk Ü. Ziraat Fak., Bitki Koruma Bülteni, 1997, 37 (3-4):101-110 .

Özbek H 2011. Korunga (Onobrychis viciifolia SCOP.): Önemli bir arı bitkisi. Uludağ Arıcılık Dergisi Mayıs 2011 / Uludag Bee Journal May 2011, 11 (2): 51-62.

Parlak AÖ, Gökkuş A, Samıkıran E, Şenol MŞ 2014. Bazı Yabani Korunga Türlerinin Morfolojik ve Agronomik Özelliklerinin İncelenmesi. ÇOMÜZF Dergisi: 2 (2): 111-117.

Rumball W, Claydon B 2005. Germplasm release 'G35' Sainfoin (Onobrychis vicifolia). Jour. Agri. Res., 48: $127-128$.

Serin Y, Tan M 2008. Baklagil Yem Bitkileri. Atatürk Üniv. Ziraat Fak. Yay., No:190, 178 s, Erzurum.

Stevovic V, Stanisavljevi R, Djurovic D 2012. Effect of row spacing on seed and forage yield in sainfoin (Onobrychis viciifolia scop.) Cultivars.Turk J Agric for 36 (2012): 35-44,C Tübitak.

Tamer A, Aydemir M, Has A 1997. Ankara ve Konya illerinde korunga ve yoncada görülen zararlı ve faydalı böcekler üzerinde faunistik çalışmalar. Bitki Koruma Bülteni, 37 (3-4): 125161.

Temel O 2010. Artvin Şavşat yöresinde korunga (Onobrycis sativa Scop.) yem verimi ve kalitesinin yüksekliğe göre değişimi. Fen Bil. Enst. Artvin Çoruh Üniv., Yüksek Lisans Tezi

Tuna C 1994. Tekirdağ Koşullarında Yetiştirilen korungada (Onobrychis sativa L.) farklı sıra aralığı ve ocağa ekimin ot ve tohum verimine etkisi. Trakya Üniv. Fen Bil. Enst. Tarla Bitkileri ABD. Yüksek Lisans Tezi. Tekirdağ, $60 \mathrm{~s}$.

Yılmaz İ, Akdeniz H, Deveci M 1999. Van sulu ve kuru koşullarında korunganın ot ve tohum verimi üzerinde bir araştırma. Türkiye 3. Tarla Bitkileri Kongresi, Cilt III, Çayır-Mera Yem bitkileri ve Yemeklik Tane Baklagiller, 256-260, Adana. 